\title{
Troubling Law's Indefinite Detention: Disability, the Carceral Body and Institutional Injustice
}

Recently, in Australia indefinite detention in prison through the forensic mental health system of disabled people ${ }^{1}$ (particularly Indigenous Australian disabled people) has been the subject of media attention, legal inquiries and international human rights condemnation (see, eg, Senate Community Affairs Reference Committee 2016). Indefinite detention has become articulated as a key site of disabled institutional injustice. Ending indefinite detention through shifting disabled people to definite periods of detention, ideally in the community, has become the focus of political discussion and disability rights advocacy (Cadwallader et al, forthcoming). I take this current moment in the politics of disabled indefinite detention as an entry point into a broader consideration of the possible limits of articulating institutional injustice by reference to the legal concept of indefinite detention.

Indefinite detention is a temporally and spatially defined legal phenomenon. Indefinite detention is conventionally understood as involving confinement pursuant to a legal or administrative order which provides no clearly defined time period for or end date to this confinement. Confinement is in a material architectural space legislated or otherwise purposed as a place of detention or secure containment (e.g. prison, mental health facility) (Senate Community Affairs Reference Committee, 2016: 5). Some critical legal scholars have argued that law's representation of time and space can obscure our ability to see injustice, notably the complicity of law in institutional injustices (see, e.g., Mawani, 2014; Veitch, 2007). This article questions the assumptions about time and space and related dichotomies of indefinite/definite and detention/liberty that mediate the legal concept of indefinite detention.

By drawing on critical disability studies to critique time and space at the intersections of disability and law, this article identifies and troubles the 'curative' (Kafer, 2013) or therapeutic interventionist impulse that sustains disabled people's exposure to detention and other coercive interventions across multiple jurisdictions, material spaces, legally ordered events and routine disability service provision. Through a case study of the official state

\footnotetext{
${ }^{1}$ This article uses the term 'disabled' to refer specifically to people with cognitive disabilities and mental health impairments, collectively those typically deemed in law as 'incapable' and subject to disability-specific interventions (Steele, 2014). It should be noted that some Indigenous Australian people resist definitions of disability (First Peoples Disability Network, 2016; Sotiri \& Simpson, 2005-2006: 432-433, 440-441).
} 
representation of the institutional life course of one Indigenous Australian woman who is disabled I demonstrate that across multiple jurisdictions, legal orders, service systems, material spaces and modes of intervention, law provides for the heightened carceral control of bodies on the basis of their designation as disabled. In being designated as disabled, bodies are positioned as necessarily and legitimately subjected to ongoing, persistent and multifarious control in a way paradigmatic of Foucault's argument of the policed subject (Foucault, 1979: 293-308) such that the disabled body itself is a carceral site (Steele, 2017a). This control exceeds conventional liberal legal understandings of indefinite detention which are linked to the legal indeterminacy of one legally ordered period of confinement in a legislated closed environment. An analysis of how law orders, constructs and legitimates carceral control of disabled people troubles present understandings of indefinite detention and illuminates the limited notions of (in)justice that these understandings allow. As such, this article builds on the argument made by the late Penelope Pether in her unfinished work, Genealogies of Indefinite Detention, that historical practices of preventive detention of the mentally ill is a 'paradigm case' of indefinite detention. The article does so by showing that analysis of contemporary practices of detention and control of disabled people across multiple across multiple jurisdictions, legal orders, material spaces and modes of intervention can further enrich and complicate our understandings of indefinite detention (including relationships between indefinite detention and settler colonialism) and, in turn, provide more complex understandings of institutional injustice.

I begin by introducing the theoretical and methodological approach. I then turn to a case study to carefully unpack the temporal and spatial dynamics of detention and broader carceral control of one Indigenous Australian woman who is disabled. I conclude by discussing the implications of my analysis for understanding the relationships between indefinite detention and institutional injustice.

\section{Law's Time and Space in 'Indefinite Detention'}

Law's designation of individuals as disabled has for centuries enabled the heightened indefinite detention of bodies across Australian (the focus of this article) and other western jurisdictions. This is by reason of 'disability-specific' laws, such as civil mental health laws enabling detention for the purposes of medical treatment and care, guardianship laws enabling detention in locked accommodation, forensic mental health laws enabling detention following a finding of unfitness or not guilty by mental illness and laws permitting restrictive 
practices typically within institutional spaces such as group homes, aged care facilities, schools and mental health facilities. Recent scholarship has begun to explore the colonial and racial underpinnings of the historical emergence, evolution and contemporary operation of disability-specific laws enabling indefinite detention (see, e.g., Blagg, Tulich \& Bush, 2017; Joseph, 2015). This recent scholarship can be situated in a broader context of critical disability scholarship which has argued that constructions of disability as 'abnormality' or 'unfitness' are situated in ongoing and ever-evolving settler colonial projects of rule (see, e.g., Erevelles, 2011; Hollinsworth, 2013).

This article explores how contemporary practices of indefinite detention of disabled people relate to settler colonialism, particularly as these practices pertain to Indigenous women who are disabled. In doing so, this article is informed by the scholarship of Australian Indigenous women, which has illuminated the serious issues of violence, criminalisation and institutional injustice confronting Indigenous Australian women (see, e.g., Behrendt, 2000, 2005: 249; Porter, 2016; Watson, 2007: 7-8, 2016). Indeed, Watson has noted the failure of the Australian state and legal system to acknowledge and remedy colonialism per se (Watson, 2007: 7) and has argued that Australian settler colonial law is itself illegitimate because it is founded on violent imposition through terra nullius (Watson 2014, 52-53), while MoretonRobinson has argued that 'patriarchal white sovereignty' has infused personhood in law (Moreton-Robinson, 2004). Writing in the North American context, Dian Million (Tanana Athabascan) has argued that settler colonial legal and political systems respond to Indigenous historical injustice pursuant to a neoliberal and interventionist logic that draws on medicalised notions of trauma. These medical notions of trauma in turn individualise harm and further impedes self-determination (Million, 2013: 11-12, 40). Million also notes that state legal jurisdiction is increasingly being extended over Indigenous people's land and lives as a strategy of colonial rule (Million, 2000: 102). A similar point has been made by some Indigenous Australian women scholars, notably in relation to the Northern Territory intervention (Watson, 2007).

These issues of violence, criminalisation and institutional injustice confronting Indigenous Australian women have been explored in different ways by non-Indigenous Australian scholars. These settler colonial and critical disability approaches offer an explanatory framework for ongoing dispossession and systemic subordination. For example, Eileen Baldry, Chris Cunneen and colleagues have argued that Indigenous Australian women are 
subjected to 'colonial patriarchy' (Baldry, Carlton and Cunneen, 2015) and that patriarchal colonialism has the 'power to adapt and endure' (Baldry and Cunneen, 2014: 285) including recent manifestations in the increasing incarceration of Indigenous Australian women (Cunneen and Rowe, 2015). Canadian scholars such as Chris Chapman and Jijian Voronka have tracked the ways in which disability diagnoses and interventions are increasingly being used to manage First Nations populations, rendering carceral interventions medically necessary, beneficial and 'noncolonial' (Chapman, 2014a; see similarly Voronka, 2013; on colonisation, mental health and the Global South see Mills 2014). Canadian feminist and critical race scholar Sherene Razack has discussed the way in which pathologising the precarity of First Nations offenders' contact with the justice system renders inevitable and legitimate their exposure to institutional violence and death (Razack, 2015). Together, this Indigenous and non-Indigenous scholarship directs critical attention to the interrelationships between violence, criminalisation and institutionalisation and the ways in which control of Indigenous people's lives and bodies is achieved not only through race but also through the legal prisms of disability and health.

Some critical legal scholars have argued that appreciating the full scope of institutional injustice requires questioning law's complicity in harms, not only materially through what law permits to be enacted on bodies, but also law's cultural or representational dominance in the meaning given to these material practices and the material bodies on which they are enacted (Cover, 1986; Veitch, 2007). To this end, one dimension of critical legal scholarship which this article draws upon is attentiveness to legal representations of space and time. Legal authority and action can be understood as not being open ended but rather as 'defined by limitations that [law] defines for itself' and that [law's] representations of its own legal and material boundaries circumvents claims made to its legitimacy (Douglas, Sarat and Umphrey, 2005: 9, emphasis in original). Moreover, some critical legal scholars have explored how injustices done to marginalised groups can be illuminated through understanding the marginalised body as a space (Delaney, 2003; Steele, 2017a) or the way in which the marginalised body has a porous relationship with material space which is mediated by law such that bodies 'take space with them' (Keenan, forthcoming). Moreover, some critical legal scholars have argued that law does not act on objective understandings of time, but produces time in ways that align with law's objectives and affirms law's legitimacy. Renisa Mawani has noted that 'juridical concepts, legal discourses, and legal authority are underwritten by and draw their meanings from the production, specification, and arrangement 
of time' (2014: 71). Yet, Mawani comments that '[a]lthough time is crucial to [law's] force and legitimacy, and its onto-epistemology - in legal scholarship, law's time has too often been assumed rather than problematized' (2014: 69). Law can produce time in order to fragment relations between events, spaces or people to render incomprehensible injustices (Mawani, 2014: 93). Critical legal scholarship on law, space and time orients us towards questioning the political limits of representations of space and time in conventional legal conceptualisations of indefinite detention.

In analysing indefinite detention specifically in relation to disability it is important to consider how law represents disabled bodies it (lawfully) detains. Critical disability studies scholarship provides tools for critiquing constructions of disability as individual, biomedical deficit and illuminating disability's status as a socially constructed abnormality. In turn, this scholarship can make apparent the contingency of law's representations of disability to broader historical and geopolitical dimensions of power and inequality related to such dynamics as colonialism, neoliberalism and globalisation. Drawing on critical disability studies scholarship means that disability is not analytically approached as a discrete, additional category of difference but instead is always coming into existence co-relationally with other dimensions of difference such as gender, race and sexuality in ways that reproduce the white male 'normate' subject (and in turn nation) (Connell, 2011; Erevelles, 2011; Hollinsworth, 2013; Soldatic, 2015; see also a similar point advanced in the disability justice approach developed by US activists such as Patty Berne, Mia Mingus and Lydia YZ Brown).

Furthermore, analysis of law's representation of disability as abnormality considers the legal possibilities for control and violence enlivened both in relation to those designated as disabled, and the mutually constituted normate legal subject (see, generally, Campbell, 2009; Goodley, 2014). Such consideration includes the colonial and racial dimensions of confinement and other non-consensual interventions of bodies designated as disabled which can expose certain racialized sub-populations of disabled people to greater risk of violence and death (see, e.g., Puar 2017; Wadiwel, 2017). Analysis also extends to considering the carnal dimensions of law's representational and material approach to disability in two respects. One respect is how lawful techniques for regulating disability work through the body (notably through diagnosis and therapeutic interventions). The other is how discourses of care, humanitarianism and benevolence which mobilise certain affective responses to the 
disabled body are harnessed to mask the regulative, punitive, violent, indeed even lethal, effects of these interventions on disabled bodies.

Some critical disability scholarship has drawn attention to the significance of temporality, both in relation to how disability is constructed as abnormality and disabled people are devalued and subjected to greater levels of permissible violence (Kafer 2013; Steele 2018 forthcoming; for a historical perspective see Baynton 2011). For example, Alison Kafer (2013) has argued that disability is understood as an unwanted form of existence such that disabled people cannot be valued in the present and can only be valued in the future if they are no longer disabled. Thus, according to Kafer, where 'disability is conceptualized as a terrible unending tragedy ... [a] better future ... is one that excludes disability and disabled bodies' (2). As such, therapeutic interventions become understood and accepted within a 'curative imaginary': 'an understanding of disability that not only expects and assumes intervention but also cannot imagine or comprehend anything other than intervention' (27, emphasis added). Critical disability scholarship, notably Kafer's concept of the 'curative', encourages us to question the self-evidence of indefinite detention and other coercive interventions, notably when these are justified on the basis of support and therapy and when they are of an ongoing and routine nature. Moreover, the notion of disabled people as 'fixed' in time resonates with the temporal construction of Indigenous people as pre-modern and inevitably destined for premature death and annihilation (Razack 2015; for a historical exploration of the emergence of these intersections see Baynton 2011), and directs critical attention to the racialized and settler colonial dimensions of indefinite detention of Indigenous Australians who are disabled.

Recent critical disability scholarship is drawing out the carceral quality of coercive interventions and control of disabled people (what I refer to as 'disability carceral scholarship'). For example, in their introduction to a ground breaking edited collection on disability and incarceration, Chris Chapman, Alison C Carey and Liat Ben-Moshe propose that the diversity of sites in which people with disability have been confined over the centuries constitutes an 'institutional archipelago' (Chapman et al. 2014:14). They argue that across individuals' lives and across macro policy shifts, disabled bodies have been confined within and moved between sites of confinement such that any 'freedom' from one site of confinement generally results in entry of these bodies into and confinement in another (Chapman et al. 2014). Disability carceral scholarship troubles accepted understandings of 
institutionalisation and incarceration in order to illuminate the carceral quality of a broader range of sites such as family homes, disability group homes, mental health facilities, and special education schools. Many of these sites are particular to people with disability and are typically viewed as therapeutic, benign and even empowering. In so doing, disability carceral scholars displace the prison as the exclusive or primary site of disabled carceral practices and unsettle the therapeutic logic that negates the carcerality of disability-specific spaces of confinement (see, e.g., Adams \& Erevelles 2017; Ben-Moshe 2017; Ben-Moshe et al. 2014; Dowse 2017; Joseph 2015; McCausland \& Baldry 2017; Spivakovsky \& Seear 2017; Spivakovsky 2014a; 2014b; 2017; Steele 2017; Voronka 2013; Wadiwel 2017). In a contribution to this scholarship, recently, I argued that the possibility (and indeed the legality) of the multiple forms of disability-specific coercive intervention in relation to disabled people is not attached to a particular material architectural space or a particular court order, but instead attaches to these individuals' bodies via medico-legal designations as disabled and travels with these individuals through time and space such that it is the disabled body that is the site of carcerality and hence the disabled body makes material architectural spaces carceral (Steele, 2017a; see also in relation to restrictive practices Steele 2018 forthcoming).

Drawing on these critical legal and critical disability approaches I propose that divisions made between indefinite and definite detention and between detention and liberty are referrable to legal representations of time and space. 'Indefinite detention' is 'indefinite' because a legal order (e.g. court order, administrative order) for a specific instance of detention provides no end date and it is 'detention' because it involves confinement in a closed material, architectural space, legally authorised and designated to provide such detention (e.g. a prison, mental health facility, immigration detention facility). What is conventionally understood as indefinite detention is defined by reference to law's understanding of time - how law sets (or, does not set) the period of confinement and by reference to a detention 'event' circumscribed by the individual legal order and its related legal process. The principal injustices of what is conventionally understood as indefinite detention are the temporal uncertainty of the singular legally ordered event of detention and being confined in a walled space as compared to being 'at liberty' in the 'community'. My analysis will signal the need to exercise caution both in taking at face value law's representation of indefinite detention and, in turn, in measuring the 'justice' of carceral control against the legal temporal ordering of detention into in/definite detention or more broadly against legal principles of freedom of liberty, non-arbitrariness and procedural 
fairness. Caution is required because a legally-oriented approach could risk erasing other forms of institutional injustice beyond those that are referrable to law's own temporal and spatial points of reference.

I now turn to explore one disabled individual's indefinite detention in the context of broader institutional dynamics of detention and coercive intervention as a way to trouble law's representation of time and space in indefinite detention and illuminate broader institutional injustices of disabled people in the criminal justice system.

\section{Methodology for Troubling Law's 'Indefinite Detention'}

Methodologically, I take as my focus one embodied individual's travels across different legal spaces, modes of intervention and periods of carceral control as a way to work outside of the temporal and spatial logic of law's representation of indefinite detention. I do so through a case study of the institutional life course of one Indigenous Australian woman who is disabled ('Wendy'2), as represented in official administrative records held by various government departments. Wendy's case study was drawn from the 'People with Mental Health Disorders and Cognitive Disabilities in the Criminal Justice System in New South Wales' dataset ('MHDCD dataset'), which is a cohort of 2,731 men and women who have been in prison in New South Wales, Australia, most of whom have been designated in the data as having cognitive impairment and/or mental illness diagnosis. The MHDCD dataset contains linked data on the life-long human services and criminal justice involvement of each individual, and was constructed by merging extant administrative records from criminal justice and human service agencies such as Attorney General's, Corrective Services, Police, Health and Community Services. Data indicates demographics, criminal justice contacts, social and health factors, and disability service usage. ${ }^{3}$

'Wendy' is a 46 year old and Indigenous Australian woman. Wendy is designated by health and justice agencies as having cognitive and psychosocial disabilities. The majority of the data on Wendy were quantitative detailing episodes of service use. However, the data also include police events narrative which is the qualitative written running record of specific

\footnotetext{
2 De-identified.

3 The author's ethics approval for this empirical research was granted by the University of Sydney Human Research Ethics Committee: Protocol No 14568. This ethics approval was ratified by the University of New South Wales Human Research Ethics Committee: HREC Ref No HC12071. The larger IAMHDCD project was granted ethics approval by the University of New South Wales HREC, NSW AHMRC and individual Aboriginal organisations with which the team worked (Baldry et al, 2015: p. 27).
} 
instances of contact an individual has had with police over their life - as an alleged offender ('person of interest' or 'POI'), victim and as a 'mentally ill person' under civil mental health legislation. Drawing on these data, a case study was constructed of Wendy's institutional life course and in this article I trace the official state representations of Wendy's movements in and out of indefinite detention and between different forms of contact with criminal justice, health and human service agencies.

In drawing on institutional data, the intention is not to displace or negate the scholarship and perspectives of Indigenous Australian women on their lives and experiences, noting the lack of recognition of the perspectives of Indigenous women and privileging of western epistemologies (see, e.g., Moreton-Robinson, 2011; Porter, 2017; Watson, 2011; in the specific context of Indigenous women who are disabled and who experience violence see Cripps, Miller \& Saxton-Barney, 2010: 4). Certainly, relying upon institutional data of the administration of law is itself to draw on a set of representations which are laden with their own logics and legitimacy about law (Rajah, 2016). As such, I use institutional data not to indicate a normative truth of the subjective experiences of 'Wendy' or of disabled Indigenous Australian women more broadly, but instead for the purpose of challenging law's selfrepresentation of indefinite detention and, in destabilising this self-representation, open up a space for others to contribute their alternative representations and experiences of carceral control and its injustices.

Wendy's case study has been selected as the focus of discussion in this article because the high number of contacts with police, incidents of incarceration and involvement with mental health and disability services enables a particularly powerful and nuanced illumination of the complexity and multi-layered nature of disabled carceral control. While Wendy's institutional life course is particular to her, it is significant to note that research by Baldry, Dowse and others on the MHDCD dataset more broadly indicates that Wendy's pattern of control is not unique to her. Baldry, Dowse and colleagues have identified that cohort members had ongoing police contact as persons of interest (as well as victims of crime and under civil mental health legislation) and periods of incarceration over their lives, as well as experiencing significant social disadvantage as adults and early childhood disadvantage through poor education outcomes, high rates of out of home care and contact with juvenile justice (Baldry et al. 2012). Baldry, Dowse and others also found that Indigenous Australians 
in the MHDCD cohort, particularly Indigenous Australian women with multiple diagnoses, were some of the most criminalised and disadvantaged (Baldry et al. 2015).

I now turn to draw out a number of dimensions in Wendy's institutional contact. This discussion is structured thematically rather than chronologically.

\section{A Range of 'Indefinite Detention' Options}

Wendy is subject to periods of indefinite detention under civil mental health legislation, guardianship law and on remand in New South Wales, Australia, as well as being subjected to multiple periods of definite detention and other forms of coercive intervention by a range of criminal justice and human service agencies. ${ }^{4}$ My discussion of Wendy begins in the 'familiar' territory of conventional indefinite detention. Wendy is subjected to a number of periods of indefinite detention under civil mental health legislation. One of these is at age 32 where she was involuntary detained in a mental health hospital upon release from a one year period of sentenced incarceration. During this period of detention, hospital staff reported Wendy as having 'absconded' and request police to immediately return her if she is found. This period of indefinite detention lasts only 2 weeks because Wendy is charged with property related offences and is remanded in custody. Wendy is not only subject to disabilityspecific indefinite detention. Wendy has 41 adult prison custody episodes over a space of 19 years. Around half of these are instances of indefinite detention on remand awaiting trial (21) for periods ranging from 1 day to 7.5 months.

The forms of detention just mentioned do not depart from the familiar territory of conventional indefinite detention - all involve undefined periods of confinement in legislatively purposed places of detention. Yet, even within the contours of conventional indefinite detention, it is apparent that disability enables additional opportunities for indefinite detention. For Wendy, civil mental health indefinite detention is not an alternative

\footnotetext{
${ }^{4}$ Wendy's case study is drawn from a project on diversion of people with cognitive impairment from the criminal justice system consisting of quantitative data (Steele, Dowse and Trofimovs, 2016) and qualitative data involving four case studies of offenders with disability. The sampling of the four case studies was purposive in order to capture individuals who have particularly complex diagnoses and criminal justice pathways. Ethics approval for this empirical research was granted by the University of Sydney Human Research Ethics Committee: Protocol No 14568. This ethics approval was ratified by the University of New South Wales Human Research Ethics Committee: HREC Ref No HC12071. This study is a nested study within the Australian Research Council (ARC) Linkage project, 'People with Mental Health Disorders and Cognitive Disabilities (MHDCD) in the Criminal Justice System (CJS) in NSW', University of NSW - Chief Investigators E. Baldry, L. Dowse and I. Webster. See generally Australians with MHDCD in the CJS Project (29 June 2012) Mental Health Disorders and Cognitive Disabilities in the Criminal Justice System <http://www.mhdcd.unsw.edu.au/australians-mhdcd-cjs-project.html>.
} 
to mainstream indefinite detention. Rather across her life she is legally designated at various times legally capable or incapable, travelling between different jurisdictional domains of criminal law and forensic and civil mental health law and is ultimately subject to both forms of indefinite detention.

\section{Multiple and Generative Nature of 'Definite' Disabled Confinement}

Wendy is also subjected to 20 periods of sentenced definite detention in prison, cycling in and out of relatively short periods of detention ranging from 5 days to 13 months. Thus, additional to conventional indefinite detention she is also subjected to definite detention which, in its frequency and its nature of generating further opportunities for additional detention, is rendered 'indefinite' in the sense of being recurring and routinized. As such, the indefinite/definite detention divide is largely artificial where one is subject to multiple successive periods of detention with no clear end to this cycle. In its submission to the Indefinite Detention Australian Senate Inquiry, the First Peoples Disability Network (2016) referred to the 'recurrent and indefinite detention' to capture this phenomenon of ongoing periods of definite detention (see also Steele 2016b).

While in adult custody, Wendy is charged with 127 offences in custody, primarily for intimidation, disobeying directions and abusive language. Wendy is noted as being a 'management problem' in custody and as having a '[h]istory of aggression and harm to others'. She spends a number of periods in 'protective' custody, as well as periods in segregation for disciplinary reasons. Therefore, additional to multiple periods of imprisonment, it is significant that these periods of imprisonment are themselves generative of new possibilities within prison for detention in different spaces and subjection to coercive interventions ('micro carceral practices') (see also Spivakovsky 2017). Wendy is not only segregated for disciplinary reasons. She also has 40 recorded instances of self-harm during her short prison episodes. For a number of these she is segregated. Wendy's self-harm and her subsequent isolation is reflective of the argument that the complex relationship between pre-existing disability, the circumstances of prison per se and the use of segregation and isolation for those at risk gives rise to a 'maddening' effect of prison (Ben-Moshe, 2017: 280282) - and, for our purposes, state complicity in the disablement and injustices against incarcerated Indigenous Australians who are disabled. 
While in prison, Wendy reports to police incidents of violence by other inmates. For example, just before her $31^{\text {st }}$ birthday, Wendy reports having been sexually assaulted by two female inmates while serving a sentence of custody. She discloses these incidents during a court appearance. The police events narrative states:

It is the belief of the prison staff that the victim will be sentenced to a mental institute for a period of time and that she only brought up the allegation of sexual assault to the judges attention so as the judge would go easy on her.

Due to the victim's mental capacity, the fact that the descriptions of the cell mates do not match the actual cell mates, the times of the incident and the continued changing of the victim story, it is doubtful that any sexual assault took place. ... The victim is a rather large female who has a history within the prison system of being violent towards herself, other prisoners and prison officers. The description given by the victim of the two offenders does not fit with the victim being so easily over powered. The victim is a rather large, strong female.

In constructing Wendy as both cunning and incapable, police negate the possibility of Wendy's victimisation in prison by reference to norms of gender, ability and noncriminality/compliance (including by reference to her history of offences committed while in custody) (see further Steele 2017b). Across Wendy's institutional pathways, disability is deployed or erased to suit particular, specific institutional outcomes - here not investigating sexual assault and keeping her in prison. This deployment of disability is arguably an additional carceral effect of state sanctioned violence that follows from indefinite and definite detention (Steele, 2016a) and in turn points to the complex institutional entanglements of victimisation and criminalisation. Yet, being designated as disabled conceals these injustices in the body under the guise of pathology, a point noted by Million who has argued in the North American context that medicalised notions of trauma have resulted in rape of Indigenous women being criminalised or trivialised through therapeutic intervention (Million, 2013: 11-12, 40).

For Wendy, police custody constitutes a further carceral space. When Wendy is not in Department of Corrective Services custody, she has multiple police custody episodes generally while she is waiting to be charged or interviewed, and including for breaches of bail. For the 12 year period of available data (from the age of 27 to age 39) Wendy has 
around 76 police custody episodes. As her contact with police begins when she is 13 years old and hence the available data is for only half of the years of her police contact, it is likely that she has had many more police custody episodes than what is in the data.

A number of scholars, across Australia and Canada, have argued that a medicalised approach to disability opens up new criminal justice possibilities for Indigenous people in settler colonial contexts (see, e.g., Chapman, 2014a; Voronka, 2013; Baldry, McCausland, Dowse \& McIntyre, 2015). These new criminal justice possibilities are evident in relation to Wendy's subjection to conventional indefinite and definite detention. The fact that these additional possibilities for incarceration are by reason of her designation as legally incapable (via diagnosed disability) rather than directly by reason of her Indigeneity allows law to represent incarceration as 'noncolonial' (Chapman, 2014a) and disconnected from larger political issues of race and colonisation, including intergenerational and historical dimensions.

My analysis so far challenges the limits of in/definite detention as a framework for articulating institutional injustice by troubling the temporal assumptions in this dichotomy. This dichotomy not only masks the effects of multiple periods of 'definite' detention, but also the focus on the 'indefinite' legal order as the site of in/justice focuses on the clean, deskbased moment of the order of detention itself and hides the material and carnal effects of incarceration regardless of its time period and casts these effects beyond law's responsibility (Cover, 1986) and legal understandings of injustice. ${ }^{5}$ In focusing on the order, the 'disabling effects and legitimacy of the prison remain intact' (Ben-Moshe, 2017: 285). Indefinite detention, as conventionally understood, contributes to a 'legally ordered suffering' (Veitch 2007; on law's complicity in historical suffering of Indigenous Australians, see Van Rijswijk and Anthony 2015). I will now problematize the spatiality of indefinite detention, which rests on a detention/liberty divide. I focus on the community (and, indeed, the body) as a carceral space for Wendy.

\section{Beyond 'Detention' Spaces: The Community and the Body as Carceral}

Wendy's first recorded police contact as a POI is at 13 years of age for stealing. Wendy has around 240 charges principally for low-level property-related offences, assault and breach of bail in the space of 25 years of available data. However, she has around 330 recorded

\footnotetext{
${ }^{5}$ Indeed, a similar problem arises in legal pedagogy where, e.g., criminal law teaching finishes at the legal moment of sentencing, with no teaching of the legal framework of incarceration itself, including the laws regulating micro carceral practices.
} 
contacts with police as a POI and an additional 30 contacts as a victim and 25 contacts as a 'patient' under civil mental health legislation. Wendy has more frequent contact with police than her formal criminal charges suggest, and this contact begins at an early age. As such her detention is but one aspect of a broader pattern of control through the criminal justice system, such that the 'community' is itself a carceral space for Wendy.

There are two key features that characterise Wendy's contact with police as a POI which enrich and complicate spatial dynamics of conventional 'detention'. I will now turn to discuss these features.

\section{Control in Out of Home Care}

Wendy's earliest contact with police is as a missing person while in out of home care ('OOHC'). Wendy is in OOHC as a child, having been removed from her parents at 2 years old. The data is scant during her early teens, but it seems that in her late teens she comes to the attention of police on a number of occasions for 'absconding' from OOHC and has contact with police as a 'missing person'. This contact as a missing person slowly morphs into contact with police for low level offending in the community such as shoplifting, showing the fluidity of 'care' and 'crime' for Wendy (see similarly Trofimovs \& Dowse, 2014: 394).

It is not only that $\mathrm{OOHC}$ generates contact with police and channelling into detention, but that OOHC itself takes on a carceral quality evident in the use by police of the term 'absconding' and the role of police in conveying young persons back to their residence (with no indication in the data that police query the reasons underlying Wendy running away from her residence). Wendy quickly goes from being 'at risk' to 'a risk' (Baldry, 2014: 376). It is also significant that as an adult Wendy has children who are removed from her care by the state, thus suggesting the intergenerational nature of this mode of carceral control which is reflected in the literature on the significance of child removal policies to the ongoing disadvantage experienced by Indigenous Australians (Cunneen and Libesman, 2000: 102103). Yet, the criminalisation of Wendy in OOHC and her subsequent positioning by the state as both a criminal and disabled/mentally ill (arguably both possible by reason of the material effects of being in $\mathrm{OOHC}$ ), individualises the historical and structural injustices of intergenerational and cyclical child removal and broader settler colonial dispossession 
(Chapman, 2014a; Voronka, 2013; see generally Anthony 2018 forthcoming), concealing these historic and ongoing injustices in the deviancy and pathology of her body.

\section{Control through Disability 'Support'}

Wendy is also detained in '[u]nexpected spaces of confinement' (Adams \& Erevelles, 2017). At age 31 Wendy begins to live in community disability supported accommodation with case management and behaviour intervention and support, following a period in prison and subsequent indefinite detention in a mental health facility. From that time until when the data end, Wendy moves between prison and various supported disability accommodation settings and locations: group homes, hospital based large scale accommodation and specialist forensic community disability supported accommodation with 24 hour supervision. Wendy's case study illustrates that the relations that order disability accommodation spaces in the 'community' provide new possibilities for police contact and that these new relations trouble the distinction undergirding the in/justice of indefinite detention between detention and liberty which grounded in material architectural legislatively purposed places of detention.

While in disability supported accommodation Wendy has contact with police in relation to property damage and assault against disability support service property and staff, seemingly because she is frustrated with the control dynamics in the accommodation. For example, one incident described by police in their events narrative states that Wendy 'was refused her daily cigarette by centre staff. The POI, who suffers from a multitude of mental disorders, responded to this by, and perhaps not surprising, smashed a window in protest'. Wendy also has contact with police related to self-harming in the accommodation setting, sometimes after an altercation with staff. At times the self-harming is dismissed in police events narrative as attention seeking (see generally Steele, 2017b).

The criminal and civil legal orders which order both Wendy's (coerced) presence in disability service space and the relations between her and staff also provide new possibilities for police contact in the 'community'. At times, Wendy's location in accommodation is linked to criminal legal orders including bail, good behaviour bonds, and court diversion orders that allow her to remain in the community conditional upon her residing at disability accommodation and/or following the directions of her case manager and staff of the accommodation. The orders place supervision and reporting obligations on the service staff, which means that staff must then report breaches of the orders to police, for example if 
Wendy does not return to the accommodation at night. It is notable that Wendy does spend periods of time in prison during the time she has accessed disability supported accommodation.

Furthermore, Wendy is under a guardianship order that includes a retrieval order. This order means that Wendy's public guardian makes decisions about where Wendy is to live and if Wendy does not live at this address then her guardian has the authority to contact the police to request that they coercively return her to that accommodation. As an aside, police are similarly involved in coercive retrieval and enforcement of 'treatment' in the context of community mental health treatment orders, which are seen as a community-based 'alternative' to involuntary detention and treatment in mental health facilities (for a critique of community treatment orders, see Fabris 2011; see also Beaupert 2018). Wendy has police contact relating to absconding from the accommodation - as she is coerced to stay there and the service has an obligation to notify police that she is missing either pursuant to her guardianship order (with retrieval order) or pursuant to a criminal legal order. In one institutional accommodation setting, Wendy is noted in the police events narratives as 'absconding' from the accommodation nearly every second day. Ultimately, whether she is charged depends in part on how supportive her case manager and the accommodation workers are. Moreover, while not apparent from the available data, disability group homes exercise their own systems of micro-rule through behaviour support plans and related systems of rewards, incentives and penalties including restrictive practices (Spivakovsky, 2017: 371375; Steele, 2014: 282, 285). Importantly, while criminal legal orders come and go depending on Wendy's offending and the temporal limits of a instance of remand/bail or sentence, the guardianship order is ongoing because it is linked to Wendy's decision making capacity and hence to her very self (see also Steele, 2017a). The guardianship order can be read by reference to Kafer's concept of the 'curative impulse' such that not only is there a range of therapeutic legal options available to detain and control Wendy within the 'community' (which includes guardianship orders), but they are invoked in a largely non-reflexive, selfevident and routine manner.

Therefore, Wendy's case study demonstrates how the 'community' including the 'disability supported' community provides opportunities for confinement outside of prison or institutional 'walls' (which possibly exceed those within conventional detention spaces (Spivakovsky, 2017: 380)). These opportunities arise because the presence of Wendy in the 
'community' is legally ordered by relations not only between Wendy and services (including OH\&S laws, duty of care and governance (Spivakovsky, 2017: 375-379)) but between Wendy, services and police that demand coercion and control (e.g. parole, bail, guardianship and diversion orders that coerce individuals to remain at an address to comply with services) and some of these legally ordered relations are enlivened in an ongoing way by reason of Wendy's disability. The disabled body itself is carceral (Steele, 2017a).

As well as being subjected to a variety of material boundaries external to the body, such as prison, mental health facilities, disability supported accommodation, and ongoing police surveillance in public space, Wendy is confined from within her body in being subjected to legally ordered mental health medication through civil mental health laws. On at least one occasion Wendy is detained in a mental health facility because she refuses to take her medication while living in the community. While conventional legal conceptualisations of detention and restraint focus on external factors which restrict an individual's movement, many interventions in the disability-specific context work to restrain and control from within (e.g. chemical restraint through forced medication) (Fabris, 2011).

Wendy's case study illustrates a number of ways in which the community, and particularly the 'disability supported' community, is a carceral space (Spivakovsky, 2017). While community sentence options are available to all offenders (e.g. probation, community service orders), what is different about Wendy is that her designation as disabled enables multiple layers of carceral control which are enlivened through disability and hence exceed a specific criminal charge and ultimately attach to her body. Some of these layers of control occur through legal orders (Steele, 2017a), but it is just as much the case that the 'community' disability profession (Spivakovsky, 2017) and 'care professions' (Chapman, 2014b) are structured (both institutionally and ethically) in ways that enable more diffused, informal and routine control of disabled people.

\section{Confinement Through Movement}

Police have powers under civil mental health legislation and guardianship legislation to deal coercively with individuals if they appear to have a mental illness. In particular, where police believe the person is experiencing a mental health issue police can take an individual to a hospital for assessment by a medical practitioner with the view of possible 'scheduling' the individual to a mental health facility for involuntary containment and treatment. The 
authority lies with medical and psychiatric professionals for determining whether they ultimately remain in the mental health facility or if they are instead shifted back into the hands of police. Thus additional to individuals being moved by police into hospitals, there is a real possibility of movement back out and into the responsibility of police, leading to a constant state of suspension between agencies.

When Wendy is 34 years old, she resides (as a condition of various criminal legal orders including probation, bail and diversionary orders) in institutional disability supported accommodation based in a hospital. The hospital staff, clearly frustrated with Wendy's behaviour (including her regularly running away from the centre), seek police assistance to move Wendy out of this accommodation through reporting her breaches of the various criminal legal orders which have placed her there and through seeking she be taken elsewhere to be assessed under civil mental health laws. In responding to such requests by hospital staff, the police events narrative notes the complexities of the mental requirements of criminal law and the resultant limitations of these mental requirements in relation to the scope of carceral control through criminal law. For example, seven months into her stay, Wendy is returned to the hospital after having absconded and then subsequently refuses to take her medication and becomes aggressive towards staff:

Police attended to sight the [missing person 'MP']. Upon arrival Police viewed the MP she did appear agitated and a little aggressive. The Nurse Unit Manager [NUM] then stated that Police were to take the MP and have her charged as she had breached her bail conditions. Police observed the bail conditions and it was noted that in fact her conditions had not been broken as the MP was residing at the [centre]. There were no such bail condition in which stated that the accused was to be under mandatory supervision 24 hours a day. After Police informed the NUM of this the NUM then attempted again to have police remove the MP from the facility by taking her to [public mental health hospital] as they believed that if Police took the MP then [public mental health hospital] would mandatorily just accept her. The Staff were advised that this is not the case. Due to the MP already being in a Government facility Police believed that there was no need for the MP's location to be altered.

Therefore, while in earlier sections I have shown the variety of legal modes and spaces available to control Wendy particularly when her body is designated as disabled, she is also 
subject to carceral control in the course of moving between these modes and spaces of able criminal and disabled patient, notably at that point of refused inclusion as a disabled patient which, contradictorily is on the basis of de-designation as disabled. De-designation as disabled supports the earlier point about the legal and institutional contingency and malleability of disability. Movement of Wendy between physical, institutional and diagnostic spaces is itself a dynamic of the carceral nature of disability, and goes to the notion that disability provides additional (rather than alternative) legal options for carceral control of disabled bodies.

\section{The Carceral Disabled Body and Legal Ordering of (In)justice}

By tracking Wendy's movements through the administrative data in and 'out' of indefinite detention and between different forms of contact with criminal justice, health and human service agencies I have illuminated a continuous control dispersed across spaces and mediated by different institutions as 'care', 'punishment' and 'protection'. Ultimately, Wendy is exposed to an ongoing continuum of practices of detention, coercive intervention and surveillance across material and legal spaces and hence to carceral control as both a disabled body and (depending on institutional and other dynamics of a specific institutional contact) a 'normal', criminal non-disabled body.

Critical criminologists and critical disability studies scholars have argued that following deinstitutionalization there has been the 'trans'-institutionalization of bodies designated as disabled due to a continuity and fluidity of institutional spaces (Ben-Moshe, 2017; BenMoshe, Chapman and Carey, 2014). This article is novel insofar as it shows the limits of the legal concept of indefinite detention to capture the complexity and insidiousness of the carceral continuum specifically for disabled people who are charged with criminal offences. In particular indefinite detention cannot capture notably more 'benevolent' or 'empowering' forms of control that are typically proposed as progressive reform alternatives to conventional indefinite detention. My analysis through Wendy's case study suggests that it is not merely the availability of multiple spaces within which disabled individuals can be confined but rather that disability itself is carceral such that the designation of disability to Wendy provides the heightened, indeed hyper, possibility for carceral control of that disabled body wherever she might be. Disability make space carceral because of the control that attaches to disabled bodies both by reason of legal orders (e.g. through guardianship and civil mental health orders) and because of the biopolitical regimes of diagnosis and 'therapeutic' 
intervention pertaining to disability generally. As such people designated as disabled who are in the criminal justice system might be paradigmatic subjects of Foucauldian discipline (Steele, 2017a), including reflecting the temporal shift from the episodic control of sovereign power (here in its modern form of state ordered period of indefinite detention) to the more dispersed and ongoing control of biopower through continuous policing mediated by different institutions (Foucault, 1979: 293-308). ${ }^{6}$ Moreover, law not only governs individual instances of control but sits at the border points between different systems of control thus facilitating seamless movement between institutions and forms of control (on a similar point, see the argument that criminalised disabled people exist in a 'liminal, marginalised community/criminal justice space' (Baldry, 2010: 261; see also Baldry, Clarence, Dowse, \& Trollor, 2013: 227)).

This article is also novel in proposing that we need to be attentive to the intersections of Indigeneity and disability not only in the identities of the individuals subjected to disabled carceral control, but in the practices of carceral control themselves. The article builds on the argument by Chapman about the 'noncolonial' possibilities of disability-based carceral interventions and Million's argument about the increased jurisdiction over Indigenous land as a form of colonial rule. Here it is the jurisdiction over the Indigenous body as a disabled body that both extends and deepens colonial rule and masks its continuities of control (and see also Blagg, Tulich \& Bush, 2017: 345) through the apolitical and pathological prism of disability. The colonial patriarchy that once operated through segregation and institutionalisation (Baldry, Carlton and Cunneen, 2016) explicitly on the basis of Indigeneity now is more diffused and medicalised as disability and health. Far from being a 'solution' to addressing Indigenous over-representation in the criminal justice system, coercive health-based interventions are part of the problem. My analysis suggests the need for more careful consideration of how 'colonial patriarchy' relates to and harnesses disability in its ongoing adaptation and endurance (Baldry and Cunneen, 2014: 285) through 'universal' and non-race specific measures (286).

Moreover, I have shown that carceral control of Wendy manifested in different material and institutional forms (both disabled and 'non-disabled') and was situated in different rationalities but remained consistent and pervasive in her life. This finding suggests that shifting from a dominant racial to disability legal, political and social discourse to rationalize

\footnotetext{
${ }^{6}$ Thank you to Dinesh Wadiwel for this insightful point.
} 
criminal justice and human service interventions in some Indigenous Australians' lives and bodies does little to disrupt the control and violence they are subjected to. Indeed, the shift from race to disability might consolidate and extend control and violence through tapping into scientifically 'objective' and purportedly depoliticized (Kafer, 2013) temporal and carnal rationalizations of the carcerality of the disabled body. The switch from one mode of control to another (portrayed in progressive reformist agendas as shifting individuals into 'treatment' and 'support' and out of prison) ignores the larger task of decolonizing both criminal justice and health/disability service systems (Blagg, Tulich \& Bush, 2017: 335). In particular, the 'solution' of the community group home is highly problematic (Chapman 2014b; Spivakovsky, 2017: 380; Steele 2017a).

My analysis suggests that disability as a discrete category of subjects of indefinite detention 'matters' here in a legal sense because of the disability-specific legal options, and that in turning to material disabled and racialized bodies the legal category of disability consolidates and extends the necropolitical management of Indigenous Australians. The designation of Indigenous Australians as disabled at its minimum results in a mundane and routinized 'slow death' (Nixon, 2013) as those designated remain caught within a complex legal network of incarceration and other forms of carceral control and their experiences of interpersonal and institutional violence remain unacknowledged, yet at the other extreme this designation can result in actual death in those situations when police resort to lethal shooting to deal with a mental health crisis, where individuals experience fatal institutional violence or when individuals self-harm and commit suicide in custody (see, e.g., Razack, 2015). Where Indigeneity itself is 'lethal', the carcerality of disability then heightens the exposure of Indigenous Australians to violence and death at the same time that the inherent racism and colonialism of this violence and death is negated under the guise of individual health issues which render inevitable these circumstances of heightened exposure (Chapman, 2014a; Razack, 2015; Puar, 2017).

Positioning the disabled body itself as the site of carcerality (Steele 2017a) highlights the dangerous possibilities of control enlivened by disability which go even beyond Keenan's observation (forthcoming) of the mobile carcerality of electronic tagging - here no electronic tag is necessary, only a diagnosis (or even a perception of a diagnosis in the case of police) and the disabled body can (to borrow from Keenan) take carceral space with it. Yet the notion of the body as a carceral site falls outside of the legal concept of indefinite detention which 
my analysis suggests might be an ableist (and arguably also 'patriarchal white sovereignty' (Moreton-Robinson, 2004)) disembodied approach because it is based on the autonomous and closed body which is typically free from intervention beyond specific criminal legal orders and beyond the walls of specific places of detention.

My analysis of disability and indefinite detention is significant not only for illuminating the ongoing carceral control of criminalised bodies designated as disabled, but also framing this control as an injustice. Mawani argues that 'Law draws its meanings and gains its authorizing force through specifications and limits on time (minimum/maximum sentences or statute of limitations, for example) and through the temporalities it inhabits and brings into being' (2014: 71). Ultimately, Wendy's case study troubles legal understandings of incarceration to be too narrowly focused on temporal and spatial circumstances of particular legally ordered instances of detention. These legal understandings obfuscate causality and continuities between periods of detention and other forms of control, across jurisdictional domains and material spaces and from both outside and within the body. As Mawani states, 'law produces, engages, and inscribes discontinuities between past, present and future to fortify its own authority, sovereignty, and legitimacy' (Mawani, 2014: 69). Law's ordering of time results in an 'organised suffering' (Veitch, 2007: 1) and, indeed, in the context of Indigenous Australians an organized annihilation (Razack, 2015). Law's dispersing of control of bodies designated as disabled across different jurisdictions, different legal orders and different material spaces and modes of intervention gives a sense of incoherency across these and renders it difficult to attribute responsibility to the state and to law for harm that occurs over time, notably 'suffering that accrues as part of an eviscerating daily life' (van Rijswijk, 2015: 332) by reason of indefinite carceral control.

Using indefinite detention as a reference point for justice demands and progressive reforms only works in a liberal politics where people are viewed as autonomous, impermeable bodies which are otherwise free from coercive interventions beyond limited legal circumstances such as sentenced penalty. Such a liberal approach takes law's account of itself at face value. In its deference to legal rights and process, this liberal approach erases law's own complicity in carceral control and hides the relational and compounding nature of multiple legal instances of confinement and other forms of control, doing nothing to confront the carceral nature of the disabled body itself. A liberal approach to indefinite detention does not address and prevent future broader institutional injustices at stake which are hinted at in the 
administrative data on Wendy: intergenerational child welfare interventions, impunity for sexual violence, and over-regulation by disability services. Through the individualising and pathologising effect of disability, Wendy's possible injustices as deeply embedded structural effects of ongoing settler colonialism simply become her problems caused by her criminality and disability. Recasting indefinite detention of Indigenous Australians in terms of disability support in the community reduces structural and historical injustices of settler colonialism and ableism to individual medical issues (for a similar argument in the context of humanitarian immigration practices specific to asylum seekers requiring medical care, see Tiktin 2011). There is no questioning of the political, historical and legal circumstances in which Wendy's disability came about, including state, legal and institutional complicity in her disablement (Puar 2017). Moreover, the very fact of the lack of attention in the administrative data to state-perpetrated disablement, violence and injustice through coercive interventions (writ instead as nonviolent, mundane and routine administration of a body) is telling of how 'legitimate' official state administrative records themselves compound official judicial and legislative representations and epistemologies of the justice of indefinite detention and other forms of carceral control. As such, these administrative record keeping systems themselves might be important sites of political intervention (Steele, 2017b).

Legal reform focused on moves from indefinite to definite detention risks working within and affirming binaries sustaining rather than undermining law's legitimacy: indefinite/definite periods of detention, arbitrary/procedurally individualised and confinement/community. While such reform agendas are important in reducing the discrimination that results in the unequal distribution of indefinite detention within the population, my concern is that these reform agendas should not be an exhaustive strategy because they operate within oppressive ableist and settler colonial conditions of structural injustice (Anthony forthcoming) which are masked as objective, apolitical and medical. In shifting from a legal vantage point to determine the (in)justice of indefinite detention, to a carnal and material vantage point of the racialized and disabled body, it might be possible for law reform agendas to move beyond the legal subject bounded by one sentence, one place and one point in time, to see a body moving through time and space caught in a continuous control that attaches to their body.

In thinking about the 'unevenness of how populations live and get to live time' (Puar, 2009: 166) we must move beyond the limitations of legal understandings of temporality and spatiality of indefinite detention. As DL Adams and Nirmala Erevelles argue, we need to 
think beyond rights and the liberal individual to an ontology of disabled life as valued and worth living (Adams \& Erevelles, 2017: 362). To this end, we need more complex relationships between disability, law, institutions and violence in order to invigorate meanings of in/justice including a greater appreciation of the complicities of law, institutions and services in injustice (Baldry, Clarence, Dowse, \& Trollor, 2013: 227) and in disability itself (Ben-Moshe, 2017: 282). In doing so, we can see and make the state account for a wider set of institutional injustices.

\section{References}

Adams DL and Erevelles N (2017) Unexpected spaces of confinement: Aversive technologies, intellectual disability, and 'bare life' Punishment \& Society 19(3): 348-365.

Anthony T (2018 forthcoming) 'They were treating me like a dog': the colonial continuum of state harms against Indigenous children in detention. Journal of State Crime.

Baldry E (2014) Disability at the margins: Limits of the law. Griffith Law Review 23(3): 370388.

Baldry E (2010) Women in transition: From prison to.... Current Issues in Criminal Justice 22(2): 253-267.

Baldry E and Cunneen C (2014) Imprisoned Indigenous women and the shadow of colonial patriarchy. Australian \& New Zealand Journal of Criminology 47(2): 276-298.

Baldry E, Carlton B and Cunneen C (2015) Abolitionism and the paradox of penal reform in Australia: Indigenous women, colonial patriarchy, and co-option. Social Justice 41(3): 168189.

Baldry E, Clarence M, Dowse L and Trollor J (2013) Reducing vulnerability to harm in adults with cognitive disabilities in the Australian criminal justice system. Journal of Policy and Practice in Intellectual Disabilities 10(3): 222-229.

Baldry E, Dowse L and Clarence M (2012) People with Intellectual and Other Cognitive Disability in the Criminal Justice System. Report for the Family \& Community Services: Ageing, Disability \& Home Care. December 2012. Sydney: UNSW. 
Baldry E and McCausland R (2017) 'I feel like I failed him by ringing the police': Criminalising disability in Australia. Punishment \& Society 19(3): 290-309.

Baldry E, McCausland R, Dowse L and McIntyre E (2015) A Predictable and Preventable Path: IAMHDCD Report. Sydney: UNSW.

Baynton DC (2011) 'These pushful days': Time and disability in the age of eugenics. Health and Disability 13(2): 43-64.

Beaupert F (2018), Freedom of opinion and expression: from the perspective of psychosocial disability and madness. Laws 7(3), DOI: 10.3390/laws7010003.

Behrendt L (2005) Law stories and life stories: Aboriginal women, the law and Australian society. Australian Feminist Studies 20(47): 245-251.

Behrendt L (2000) Consent in a (neo)colonial society: Aboriginal women as sexual and legal 'other'. Australian Feminist Studies 15(33): 353-367.

Ben-Moshe L (2014), Alternatives to (disability) incarceration. In: Ben-Moshe L, Chapman C and Carey AC (eds) Disability Incarcerated: Imprisonment and Disability in the United States and Canada. New York: Palgrave Macmillan, pp.255-272.

Ben-Moshe L (2017) Why prisons are not 'the new asylums'. Punishment \& Society 19(3): 272-289.

Ben-Moshe L, Chapman C and Carey AC (eds) (2014) Disability Incarcerated: Imprisonment and Disability in the United States and Canada. New York: Palgrave Macmillan.

Ben-Moshe L and Stewart J (2017) Disablement, prison and historical segregation: 15 years later. In: Malhotra R (ed) Disability Politics in a Global Economy: Essays in Honour of Marta Russell. Abingdon, Oxon; New York, New York State: Routledge, pp.87-104.

Blagg H, Tulich $\mathrm{T}$ and Bush Z (2017) Indefinite detention meets colonial dispossession: Indigenous youths with foetal alcohol spectrum disorders in a white settler justice system. Social \& Legal Studies 26(3): 333-358. 
Cadwallader JR, Spivakovsky C, Steele L and Wadiwel D (2018 forthcoming) Institutional violence against people with disability: Recent legal and political developments. Current Issues in Criminal Justice.

Campbell FK (2009) Contours of Ableism: The Production of Disability and Abledness. Hampshire and New York: Palgrave Macmillan.

Chapman C (2014a) Five centuries' material reforms and ethical reformulations of social elimination. In: Ben-Moshe L, Chapman C and Carey AC (eds) Disability Incarcerated: Imprisonment and Disability in the United States and Canada. New York: Palgrave Macmillan, pp.25-44.

Chapman C (2014b) Becoming perpetrator: How I came to accept restraining and confining disabled Aboriginal children. In: Burstow B, LeFrancois BA and Diamond S (eds) Psychiatry Disrupted: Theorizing Resistance and Crafting the (R)evolution. Montreal, Kingston, London \& Ithaca: McGill-Queen's University Press, pp.16-33.

Chapman C, Carey AC and Ben-Moshe L (2014) Reconsidering confinement: Interlocking locations and logics of incarceration. In L Ben-Moshe, C Chapman \& AC Carey (eds), Disability incarcerated: imprisonment and disability in the United States and Canada, Palgrave Macmillan, New York, pp.3-24.

Connell R (2011) Southern bodies and disability: Re-thinking concepts. Third World Quarterly 32(8): 1369-1381.

Cover R (1986) Violence and the word. Yale Law Journal 95: 1601-1629.

Cripps K, Miller L and Saxton-Barney J (2010) 'Too hard to handle': Indigenous victims of violence with disabilities. Indigenous Law Bulletin 7(21): 3-6.

Cunneen C and Libesman T (2000) Postcolonial trauma: The contemporary removal of Indigenous children and young people from their families in Australia. Australian Journal of Social Issues 35(2): 99-115.

Cunneen C and Rowe S (2015) Decolonising Indigenous victimisation. In: Wilson, D and Ross, S (eds), Crime, Victims and Policy: International Contexts, Local Experiences. Hampshire: Palgrave Macmillan, pp.10-32. 
Davis LJ (1995) Enforcing Normalcy: Disability, Deafness and the Body. Verso.

Delaney D (2003) Law and Nature. Cambridge: Cambridge University Press.

Douglas L, Sarat A and Umphrey MM (2005) At the limits of law: An introduction. In: Douglas L, Sarat A and Umphrey MM (eds), The Limits of Law. Stanford University Press, pp.1-20.

Dowse L (2017) Disruptive, dangerous and disturbing: The "challenge" of behaviour in the construction of normalcy and vulnerability. Continuum 31(3): 447-457.

Erevelles N (2011) Disability and Difference in Global Contexts: Enabling a Transformative Body Politic. New York: Palgrave Macmillan.

Fabris E (2011) Tranquil Prisons: Chemical Incarceration under Community Treatment Orders. Toronto: University of Toronto Press.

First Peoples Disability Network (2016) Aboriginal and Torres Strait Islander Perspectives on the Recurrent and Indefinite Detention of People with Cognitive and Psychiatric Impairment. Submission to the Senate Inquiry on the Indefinite Detention of People with Cognitive and Psychiatric Impairment. Available at: http://fpdn.org.au/wp-content/uploads/2016/09/SenateInquiry-Indefinite-Detention-Submission_Final.pdf

Foucault M (1979) Discipline and Punish: The Birth of the Prison. London and New York: Penguin (Alan Sheridan trans, Penguin) [trans of: Surveiller et Punir: Naissance de la Prison (first published 1975)].

Goodley D (2014) Dis/Ability Studies: Theorising Disablism and Ableism. Abingdon: Routledge.

Hollinsworth D (2013) Decolonizing Indigenous disability in Australia. Disability \& Society 28(5): 601-615.

Joseph AJ (2015) Deportation and the Confluence of Violence Within Forensic Mental Health and Immigration Systems Basingstoke: Palgrave-Macmillan.

Kafer A (2013) Feminist, Queer, Crip. Bloomington: Indiana University Press. 
Keenan S (forthcoming) A prison around your ankle and a border in every street: Theorising law, space and the subject. In: Philippopoulos-Mihalopoulos A (ed) Routledge Handbook of Law and Theory. Abingdon: Routledge.

Mawani R (2014) Law as temporality: Colonial politics and Indian settlers. UC Irvine Law Review 4: 65-95.

McCausland R and Baldry E (2017) 'I feel like I failed him by ringing the police': Criminalising disability in Australia. Punishment \& Society 19(3): 290-309.

Million D (2013) Therapeutic Nations: Healing in an Age of Indigenous Human Rights Tucson: University of Arizona Press.

Million D (2000) Policing the Rez: Keeping no peace in Indian Country. Social Justice 27(3): $101-119$.

Mills C (2014) Decolonizing Global Mental Health: The Psychiatrization of the Majority World: London \& New York: Routledge.

Moreton-Robinson AM (2011) The white man's burden: Patriarchal white epistemic violence and Aboriginal women's knowledges within the academy. Australian Feminist Studies 26(70): 413-431.

Moreton-Robinson A (2004) The possessive logic of patriarchal white sovereignty: The high court and the Yorta Yorta decision. Borderlands e-journal 3(2). Retrieved from http://www.borderlands.net.au/vol3no2_2004/moreton_possessive.htm.

Nixon R (2013) Slow Violence and the Environmentalism of the Poor. Cambridge: Harvard University Press.

Porter A (2017) Seagull syndrome: Relationships between patrol workers and government officials in NSW, Australia. International Journal for Crime, Justice and Social Democracy 6(1): $35-50$. 
Porter A (2016) Reflections on the coronial inquest of Ms Dhu. Human Rights Defender. 25(3): 8-11.

Puar JK (2009) Prognosis time: Towards a geopolitics of affect, debility and capacity. Women \& Performance: A Journal of Feminist Theory. 19(2): 161-172.

Puar J (2017) Right to Maim: Debility, Capacity, Disability. Durham \& London: Duke University Press.

Rajah J (2016) Law as record: The death of Osama bin Laden. NoFo 13: 45-69.

Razack, S (2015) Dying From Improvement: Inquests and Inquiries into Indigenous Deaths in Custody. Toronto: University of Toronto Press.

Senate Community Affairs Reference Committee (2016) Indefinite Detention of People with Cognitive and Psychiatric Impairment in Australia, Canberra: Commonwealth of Australia.

Soldatic K (2015) Post colonial re productions: Disability, indigeneity and the formation of the white masculine settler state of Australia. Social Identities 21(1): 53-68.

Sotiri M and Simpson J (2005-2006) Indigenous people and cognitive disability: An introduction to issues in police stations. Current Issues in Criminal Justice 17(3): 431-443.

Spivakovsky C (2017) Governing freedom through risk: Locating the group home in the archipelago of confinement and control Punishment \& Society 19(3): 366-383.

Spivakovsky C (2014a) From punishment to protection: Containing and controlling the lives of people with disabilities in human rights. Punishment \& Society 16(5): 560-577.

Spivakovsky C (2014b) Making dangerousness intelligible in intellectual disability. Griffith Law Review 23(3): 389-404.

Spivakovsky C and Seear K (2017) Making the abject: Problem solving courts, addiction, mental illness and impairment. Continuum 31(3): 458-469.

Steele L (2018 forthcoming) Temporality, disability and institutional violence: Revisiting In Re F. Griffith Law Review. 
Steele L (2017a) Disabling Forensic Mental Health Detention: The Carcerality of the Disabled Body. Punishment \& Society 19(3): 327-347.

Steele L (2017b) Policing normalcy: Sexual violence against women offenders with disability. Continuum 31(3): 422-435.

Steele L (2016a) Submission on the Consultation Paper on Criminal Justice to the Australian Royal Commission into Institutional Responses to Child Sexual Abuse.

Steele L (2016b) Submission to the Senate Community Affairs References Committee Inquiry into the Indefinite Detention of People with Cognitive and Psychiatric Impairment in Australia.

Steele L (2014) Disability at the Margins: Diversion, Cognitive Impairment and the Criminal Law. PhD thesis, University of Sydney, Australia.

Steele L, Dowse L and Trofimovs J (2016) Who is diverted?: Moving beyond diagnosed impairment towards a social and political analysis of diversion Sydney Law Review 38(2): 179-206.

Tiktin M (2011) Casualties of Care: Immigration and the Politics of Humanitarianism in France. Berkeley, Los Angeles \& London: University of California Press.

Trofimovs J and Dowse L (2014) Mental health at the intersections: The impact of complex needs on police contact and custody for Indigenous Australian men. International Journal of Law and Psychiatry 37: 390-398.

Van Rijswijk H (2015) Towards a literary jurisprudence of harm: Rewriting the Aboriginal child in law's imaginary of violence. Canadian Journal of Women and the Law 27(2): 311335.

Van Rijswijk $\mathrm{H}$ and Anthony $\mathrm{T}$ (2015) Can the law adjudicate historical suffering? Melbourne University Law Review 36: 618-655.

Veitch S (2007) Law and Irresponsibility: On the Legitimation of Human Suffering. Abingdon and New York: Routledge-Cavendish. 
Voronka J (2013) Rerouting the weeds: The move from criminalizing to pathologizing 'troubled youth' in The Review of the Roots of Youth Violence. In: Lefrancois B, Menzies R and Reaume G (eds) Mad Matters: A Critical Reader in Canadian Mad Studies. Toronto: Canadian Scholars Press Inc, pp.309-322.

Wadiwel D (2017) Disability and torture: Exception, epistemology and 'black sites'." Continuum. 31(3): 388-399.

Watson I (2011) Aboriginal(ising) international law and other centres of power. Griffith Law Review: 20(3) 619-640.

Watson I (2014) First Nations stories, Grandmother's law: Too many stories to tell. In: Douglas H, Bartlett F, Luker T and Hunter R (eds) Australian Feminist Judgments: Righting and Rewriting Law: Oxford \& Portland, Oregon: Hart Publishing, pp.41-54.

Watson I (2007) The Aboriginal state of emergency arrived with Cook and the First Fleet Australian Feminist Law Journal. 26: 3-8. 